\title{
A Caddo Archeology Map
}

Timothy K. Perttula

Heritage Research Center, Stephen F. Austin State University

Follow this and additional works at: https://scholarworks.sfasu.edu/ita

Part of the American Material Culture Commons, Archaeological Anthropology Commons, Environmental Studies Commons, Other American Studies Commons, Other Arts and Humanities Commons, Other History of Art, Architecture, and Archaeology Commons, and the United States History Commons

Tell us how this article helped you.

This Article is brought to you for free and open access by the Center for Regional Heritage Research at SFA ScholarWorks. It has been accepted for inclusion in Index of Texas Archaeology: Open Access Gray Literature from the Lone Star State by an authorized editor of SFA ScholarWorks. For more information, please contact cdsscholarworks@sfasu.edu. 
A Caddo Archeology Map

Creative Commons License

(c) $)(1)$ (9)

This work is licensed under a Creative Commons Attribution-NonCommercial 4.0 International License 


\section{A CAdDo ARCheology MAP}

\section{Timothy K. Perttula}

Archeologists use the term "Caddo" to refer to the many archaeological sites and abundant material remains that the ancestors of the modern Caddo peoples left behind over a large area of four different states, including eastern Texas, northwestern Louisiana, southwestern Arkansas, and eastern Oklahoma, traditionally centered on the Red River and its tributary streams. That record is marked by the remains of farmsteads, hamlets, villages, family and community cemeteries, and many small and large mound centers with public structures on and off mound platforms, plazas, and the burials of the social and political elite in and off mounds, as well as a rich material culture, especially their well-crafted ceramic wares. The peoples that lived in this area shared a common cultural heritage and native history that spanned more than a millennium.

There have been almost as many maps prepared showing what was thought to be the boundaries of the Caddo archeological area as there have been archeologists who have studied the archeological record of the Caddo people. Part of the differences likely relate to (1) the state of knowledge of Caddo archeology at the time the various maps were prepared, (2) differences between archeologists in the criteria being employed to define the Caddo archeological record at specific times and places, and (3) the inherent difficulty in defining boundaries between ancestral peoples and cultures in what must have been fluid and shifting zones of shared cultural practices, material culture traditions, and biological and genetic relationships.

These considerations led to the question: based on current (2011) understandings of Caddo archeology, what do Caddo archeologists consider as the areas where the Caddo peoples lived in ancestral times? In other words, what I was interested in ascertaining was the maximum spatial and geographical extent of Caddo communities and settlements between ca. A.D. 800 and ca. A.D. 1685, before Europeans made any sustained appearance among the Caddo peoples.

I posed this question to experienced Caddo archeologists that work in the four states of the Caddo area, namely: Dr. Ann Early (State Archeologist, Arkansas Archeological Survey, Fayetteville, Arkansas), Dr. Mary Beth Trubitt (Arkansas Archeological Survey, Arkadelphia, Arkansas), Jeffrey S. Girard (Regional Archeology Program, Department of Social Sciences, Northwestern State University, Natchitoches, Louisiana), Dr. Robert L. Brooks (State Archeologist, Oklahoma Archeological Survey, Norman, Oklahoma), and Ross C. Fields (Prewitt \& Associates, Inc., Austin, Texas). Specifically, I provided them with a base map of the region, and requested that these Caddo archeologists plot on the map the maximum extent through time (ca. A.D. 800-1685) of what they considered to be (on whatever criteria) the Caddo culture-geographical area for the state they knew best. I added my input for the East Texas area. The resulting map is shown as Figure 1. 


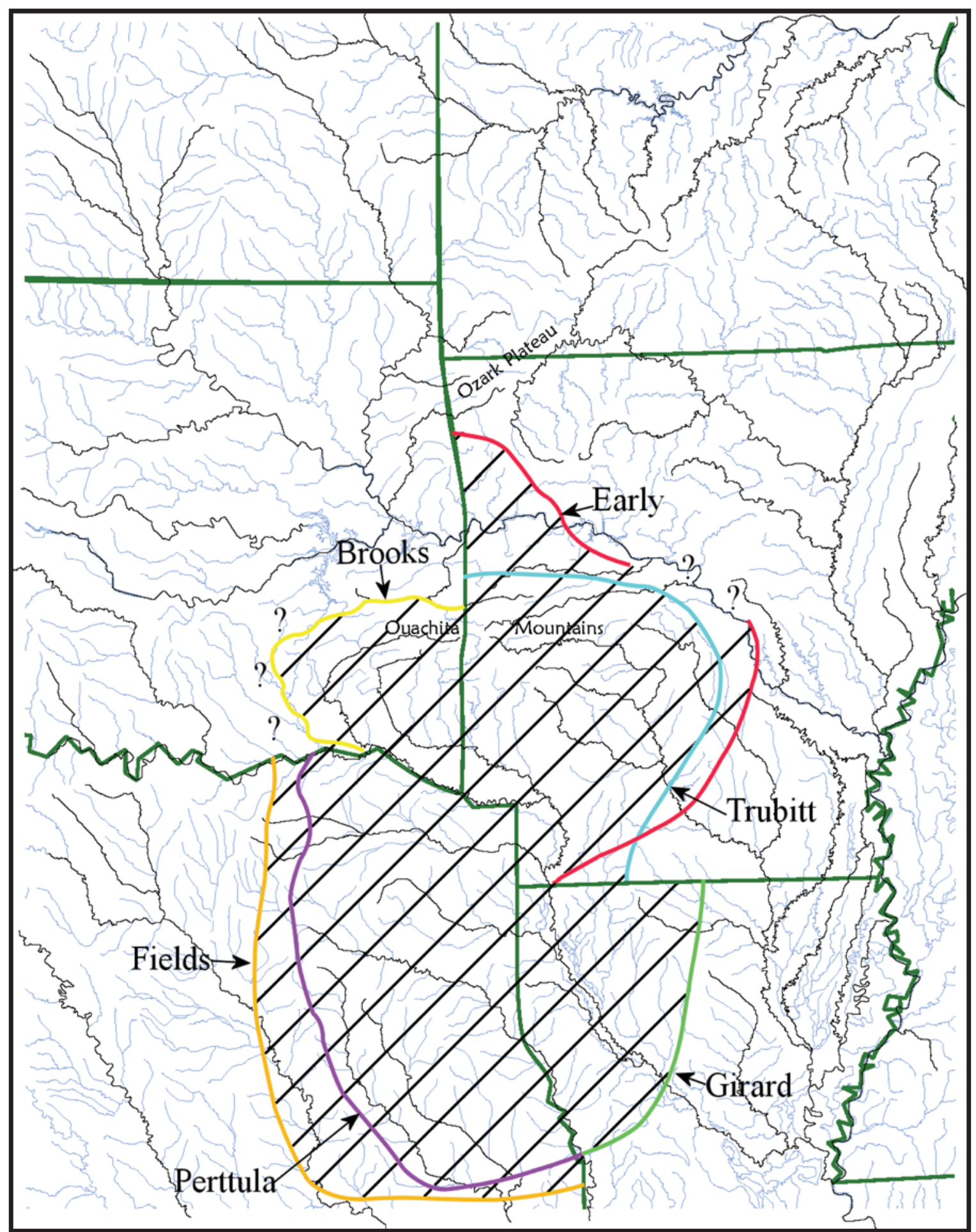

Figure 1. A composite Caddo archeology map for southwest Arkansas, northwest Louisiana, eastern Oklahoma, and east Texas. Drawn by Lance Trask. 
An examination of Figure 1 clearly shows that the "boundaries" vary from state to state, and on this small sample of Caddo archeologists, there does not appear to be a consensus on what constitutes the estimated spatial extent of Caddo archeological sites across the four-state region. In Arkansas, Dr. Early includes part of the Arkansas River basin and Ozark Plateau within a Caddo archeological area, with some questions about the extent and inclusion of the middle part of the Arkansas River area. ${ }^{1}$ Dr. Trubitt only includes several tributary stream basins of the Arkansas River, but excludes the main part of the Arkansas River basin. ${ }^{2}$ Boundaries to the south (into Louisiana), mainly the inclusion or not of parts of the Ouachita River basin, and to the west (into Oklahoma) are spatially disjunctive (see Figure 1), especially with respect to the inclusion of the Arkansas River basin and adjoining Ozarks.

Jeffrey S. Girard places the eastern extent of the Caddo area in Louisiana farther east, into the upper part of the Bayou d'Arbonne stream basin, than the boundaries as drawn for the southwestern part of Arkansas (see Figure 1). The southern boundary of Caddo archeological sites along the Red River is placed just below the Natchitoches, Louisiana area, while their western extent is near the southern end of modern day Toledo Bend Reservoir.

In Oklahoma, Dr. Brooks excludes the Arkansas River basin and any portion of the Ozarks as part of the Caddo archeological area (see Figure 1). In a personal communication on June 2, 2010, Dr. Brooks noted that he does "see some significant distinctions between the Red and Arkansas River drainages. I suspect these people may be related biologically if not culturally - but at the same time, I think they would distinguish themselves from one another. (Just as the Caddo distinguish between their confederacies.)" He questions what is known about the western periphery of the Caddo, west of the Ouachita Mountains.

In East Texas, both Ross C. Fields and I have placed the western boundary of the Caddo archeology area along the Red River farther west than Dr. Brooks had, as he drew the boundary basically at the confluence of the Kiamichi River and the Red River (see Figure 1). Fields and I place that boundary on one side or the other of Bois d'Arc Creek, a number of miles upstream from the Red-Kiamichi confluence. Fields also drew the Caddo archeology boundary to include portions of the Trinity River basin, including lands west of the Trinity River itself $^{3}$, while I placed the western extent of the Caddo archeological area to encompass much of the Neches River basin, but not the Trinity River basin. Based on ethnographic and historical records alone, the area east of the Trinity River has been considered the Caddo homeland (Foster 2008:195), but Foster (2008:208-209) also has noted that early $18^{\text {th }}$ century historical documents place "permanent Hasinai farming villages established ten to twenty miles west of the Trinity."

In sum, while I received input from experienced Caddo archeologists, a definitive map that depicts the spatial extent of the Caddo archeological area in Arkansas, Louisiana, Oklahoma, and Texas still remains to be developed. As the composite map indicates, the Caddo archeological area is considered to cover a ca. $235 \mathrm{x}$ 350 mile area (ca. 82,200 square miles) of these four states. The archeological reality is very different than the historic domain of the Caddo people as portrayed by Helen Tanner (1993:6), as Tanner defined the "original Caddo country, a realm that extended about four hundred miles east to west, and four hundred miles north to south."

There are spatial discontinuities between each of the states in the plotting of the maximum extent of the geographic landscape of the Caddo peoples between ca. A.D. 800-1685. This is despite more than 100 years of archeological investigations of Caddo sites. It is suspected that the re-thinking of the cultural affiliations of certain archeological phases and traditions has played a large role in the existence of these disjunctions, as has the lack of modern research in some areas. Certainly the most disjunctive geographical conclusion of this mapmaking exercise is the exclusion by Dr. Brooks and Dr. Trubitt of the archeology of the Arkansas River basin and major tributaries in both eastern Oklahoma and parts of southwest Arkansas, contra the spatial extent of Caddo archeological sites depicted by Dr. Early. 


\section{End Notes}

1. In an August 12, 2011 e-mail to the author, Dr. Ann Early noted that she "had the opportunity to actually handle pottery from some of those sites on the Arkansas River, especially Greer. There is a large collection from a cemetery near the Greer Mound in the Lemley Collection, and we documented it the last time we were at Gilcrease. All of the pots in that cemetery are Caddo, comparable to the Social Hill phase pottery in the Ouachita valley. The Kuykendall Brake Site has similar pottery. So, today I'd firm up that loop de loop [area of question marks from the Little Rock to Pine Bluff area on the Arkansas River, see Figure 1) I did in my map drawing."

2. The map that Mary Beth Trubitt sent me showing Caddo boundaries in southwest Arkansas was one she "had used for a recent Caddo Conference presentation on radiocarbon and other dates from Caddo sites in southwest Arkansas. Because we were focusing that research on this part [of the] region, it was bounded arbitrarily on the west and south by the state lines, and on the north by the Arkansas River valley. If I were to draw a map of Caddo homelands as a whole, I'd include parts of Louisiana, Texas, Oklahoma, and more of Arkansas. Yes, I'd include parts of the Arkansas River valley around Fort Smith, and yes, I'd include parts of the Ozarks in northwest Arkansas. I think there are enough similarities between northern (Arkansas River) Caddo and southern (Red River) Caddo to include both as Caddo" (August 23, 2011 e-mail from Trubitt to the author).

3. Ross C. Fields, in an August 19, 2011 e-mail, explained that in drawing the western boundary of Caddo groups in East Texas he "was trying to depict what I think was the maximum territorial extent (for residential purposes) of the Caddo in Texas in prehistoric times. It goes far enough west to include some marginal things like Cooper Lake, Cedar Creek [Reservoir], Richland Creek [Reservoir], and Jewett. I suspect most of what we see in some of these places (particularly Richland Creek and Jewett) are local non-Caddo developments, but I am open to the possibility that Caddo peoples occasionally moved out there and tried to make a go of it. I think McGuire's Garden [41FT425, at the Jewett Mine, see Gadus et al. 2002] is one of those. Hence, the western line I drew can be seen as "Caddo homeland plus," exclusive of Caddo hunting, trading, etc."

\section{Acknowledgments}

I appreciate the input I received from Ann Early, Mary Beth Trubitt, Jeff Girard, Robert L. Brooks, and

Ross C. Fields on the maximum extent of the Caddo archeological area. Thanks also to Robert Cast, Ann Early, and Mark Walters for comments on an earlier version of this paper.

\section{References Cited}

Foster, William C.

2008 Historic Native Peoples of Texas. University of Texas Press, Austin.

Gadus, E. Frances, Jennifer K. McWilliams, and Ross C. Fields

2002 Data Recovery Excavations at the McGuire's Garden Site (41FT425), Jewett Mine, Freestone County, Texas. Reports of Investigations No. 134. Prewitt and Associates, Inc., Austin.

Tanner, Helen H.

1993 The Caddos in the Era of the Republic of Texas. 3 Parts. Caddo Nation News 2(2-4). 